\title{
Identification and sequence analysis of arginine vasopressin mRNA in normal and Brattleboro rat aortic tissue
}

\author{
I Méchaly, F Macari ${ }^{1,2}$, C Lautier ${ }^{1,2}$, J-J Serrano, G Cros and F Grigorescu ${ }^{1,2}$ \\ Laboratoire de Pharmacologie, UPRES EA 2035, Faculté de Pharmacie, 34060 Montpellier, France, ${ }^{1}$ Centre de Recherche de Biochimie \\ Macromoléculaire (CRBM), CNRS-ERS 155, 34033 Montpellier, France and ${ }^{2}$ Laboratoire d'Endocrinologie Moléculaire, Institut Universitaire \\ de Recherche Clinique (IURC), 34093 Montpellier, France \\ (Correspondence should be addressed to F Grigorescu, IURC-Molecular Endocrinology, 75 Rue de la Cardonille, 34093 Montpellier Cedex 5, France)
}

\begin{abstract}
Arginine vasopressin (AVP), a hormone of the hypothalamic-pituitary axis, was also localized in peripheral tissues. To explore AVP precursor gene expression at the vascular level, we have investigated gene transcripts by reverse transcription-polymerase chain reaction (RT-PCR) and sequencing in aortic tissue of normal rat and in the particular genetic condition of the homozygous (di/di) Brattleboro rat strain suffering from diabetes insipidus. In these rats, a gene deletion induces an unprocessed AVP precursor in the hypothalamus with undetectable immunoreactive AVP, in contrast to the detection of immunoreactive material at the vascular level. In normal rats, using primers complementary to exon 1 and 3 of the AVP neurophysin precursor gene, RT-PCR and sequencing revealed transcripts of the expected size from aorta, mesenteric artery and hypothalamus with normal, authentic sequences. Removal of aortic endothelium severely reduced the amounts of transcripts, suggesting their main endothelial origin. In Brattleboro rats, transcripts of similar size were obtained from aorta and hypothalamus and sequencing revealed the homozygous deletion $(\Delta \mathrm{G} 316)$ in both tissues, identical to that found in genomic DNA $(\Delta \mathrm{G} 1864)$. While sequence data from normal rats provide the first direct evidence for the presence of AVP precursor transcripts in rat aortic tissue, identification of the deleted sequence of transcripts in Brattleboro rat aorta suggests that tissue-specific mechanisms are operating for the expression of vasopressin neurophysin precursor in peripheral vascular tissue compared with the hypothalamus.
\end{abstract}

European Journal of Endocrinology 139 123-126

\section{Introduction}

Arginine vasopressin (AVP), synthesized as part of an AVP-neurophysin-II precursor in the supraoptic and paraventricular nuclei of the hypothalamus, is also expressed in peripheral tissues, including adrenals, ovary and testis $(1,2)$. AVP-like material, similar to that found in the hypothalamus has also been detected by immunocytochemistry in endothelial cells and by radioimmunoassay in numerous vascular tissues $(3-7)$. AVP precursor gene expression has been explored at the vascular level by ribonuclease protection assay in both intact and endothelium-denudated rat aorta and, more recently, by reverse transcription-polymerase chain reaction (RT-PCR) in primary cultured aortic smooth muscle cells $(8,9)$.

In a particular genetic condition, the homozygous (di/di) Brattleboro rat, the AVP precursor gene contains a single nucleotide deletion $(\Delta \mathrm{G} 1864$ corresponding to $\Delta \mathrm{G} 316$ on the cDNA) which, despite efficient transcription, gives rise to an altered C-terminus precursor unable to enter the secretory pathway in the hypothalamus $(10,11)$. Anti-AVP antibodies failed to detect both hypothalamic and plasmatic AVP in Brattleboro rats, but revealed AVP-like material in mesenteric artery or aortic tissue in amounts similar to those measured in normal animals (7). These findings in Brattleboro rats raise the question whether vascular AVP-like material is the product of a different gene, an alternatively spliced mRNA, or a differently processed precursor (3). To understand AVP precursor gene expression at the vascular level, we have investigated gene transcripts by RT-PCR and sequencing in aortic tissue of normal and Brattleboro rats. We report here that in the normal rat aortic AVP precursor transcripts are of preferential endothelial origin. In homozygous Brattleboro rats, since hypothalamic and aortic transcripts have identical sequences, it is suggested that some different mechanisms may be responsible for the expression of the AVP precursor in peripheral vascular tissue compared with the hypothalamus.

\section{Materials and methods}

\section{Tissues, RNA and DNA extraction}

Adult male Wistar rats were obtained from IFFA Credo (Romans, France) and homozygous (di/di) Brattleboro 
rats were kindly provided by Dr L Bankir (INSERM U90, Hôpital Necker, Paris, France). Hypothalamus and aorta were rapidly removed, frozen in liquid nitrogen and stored at $-80{ }^{\circ} \mathrm{C}$. Aortic endothelium was removed by abrasion of the luminal face. Total cytoplasmic RNA was extracted using RNA B (Bioprobe Systems, Montreuil Sous-Bois, France) and its integrity was confirmed by visualisation of $28 \mathrm{~S}$ and $18 \mathrm{~S}$ ribosomal RNA on $1.2 \%$ agarose gel. Genomic DNA was extracted from blood using the Puregene DNA isolation kit (Gentra Systems, Minneapolis, MN, USA).

\section{RT-PCR}

Total RNA $(5 \mu \mathrm{g})$ was converted to single-strand cDNA using reverse transcriptase (Superscript II RNase $\mathrm{H}^{-}$, Life Technologies SARL, Cergy Pontoise, France). The reaction was performed in $20 \mu \mathrm{l}$ mixture containing $20 \mathrm{U}$ human placental RNase inhibitor (Amersham International plc, Amersham, Bucks, UK), $0.5 \mathrm{mmol} / \mathrm{l}$ dNTP mixture, $10 \mathrm{mmol} / \mathrm{l}$ dithiothreitol, $0.5 \mu \mathrm{g}$ oligo $\mathrm{dt}$ $12-18$ and $200 \mathrm{U}$ reverse transcriptase. RNA template was eliminated in control experiments. Molecular size markers were from Boehringer Mannheim (Maylan, France). Specific primers complementary to rat hypothalamic cDNA sequence (12) were used including $5^{\prime}$ primer from exon 1 (bp 131-152) and two $3^{\prime}$ primers from exon 3 corresponding to bp 487-508 and 420444 respectively: 5'VP1: 5' ATCCGACATGGAGCTGAGACA 3', 3'VP1: 5'GCAGAATCCACGGACTCTTGT 3', 3'VP2: 5' GCCCGTCCAGCTGCGTGGCGTTGCT 3'.

PCR was performed on $10 \mu \mathrm{l}$ single-stranded cDNA as template in a $50 \mu \mathrm{l}$ reaction mixture containing $0.3 \mu \mathrm{mol} /$ $\mathrm{l}$ of each primer, $200 \mathrm{mmol} / \mathrm{l} \mathrm{dNTP,} 3 \mathrm{mmol} / \mathrm{l} \mathrm{MgSO}_{4}$ and 1 U Vent DNA polymerase (New England Biolabs, Beverly, MA, USA). The reaction was performed in an ABI 2400 termocycler (Perkin Elmer, Applied Biosystems, Roissy, France). After an initial 5 min denaturation at $96^{\circ} \mathrm{C}, 30$ cycles were performed: 1 min denaturation at $96^{\circ} \mathrm{C}, 1 \mathrm{~min}$ annealing at $60-64^{\circ} \mathrm{C}$ and $1 \mathrm{~min}$ elongation at $72^{\circ} \mathrm{C}$. PCR products ( 5 to $10 \mu \mathrm{l}$ ) were electrophoresed on $1.2 \%$ agarose gels in $1 \times$ tris-borate-EDTA buffer. PCR was performed under the same conditions on $0.5 \mu \mathrm{g}$ DNA.

\section{Sequence analysis}

PCR products from Brattleboro rat aorta were recovered using a Qiagen gel extraction kit (Qiagen S.A., Courtaboeuf, France). To increase the amount of DNA, products were re-amplified before sequencing by heminested PCR using $5^{\prime} \mathrm{VP} 1$ and $3^{\prime} \mathrm{VP} 2$ primers. All PCR products from normal and Brattleboro rats were then purified on Microcon 100 (Amicon, Beverly, MA, USA). Automatic sequencing was performed on an ABI 373A DNA sequencer from both ends using the same primers as for PCR reaction and AmpliTaq FS ABI PRISM Dye Terminator Cycle Sequencing Kit (Perkin Elmer, Applied Biosystems).

\section{Results}

\section{Detection of AVP precursor gene transcripts by RT-PCR in rat aorta}

Specific primers $5^{\prime} \mathrm{VP} 1$ and $3^{\prime} \mathrm{VP} 1$ were used to reveal transcripts from both hypothalamic and vascular tissues. RT-PCR products were detected as single bands of the predicted size of 378 and $377 \mathrm{bp}$ for normal and Brattleboro rats respectively. RT-PCR products from the hypothalamus displayed strong signals while those from mesenteric artery and aortic tissues were lower. No signal was detected in the absence of RNA template (Fig. 1A).

When the endothelium was removed, the amount of RT-PCR product was dramatically reduced. However, a faint band of $378 \mathrm{bp}$ was still observed from endothelium-free aortic preparations (Fig. 1B).

\section{Sequencing of PCR products}

As expected, RT-PCR products from normal rat hypothalamus displayed the authentic AVP precursor gene sequence (12). Sequence of transcripts from Brattleboro rat hypothalamus displayed the homozygote deletion $(\Delta G)$, identical to that found at nucleotide 1864 in the genomic DNA of homozygous (di/di) rats (data not shown). Sequencing in Brattleboro rat aortic preparations was performed in hemi-nested PCR products of $316 \mathrm{bp}$ using $5^{\prime} \mathrm{VP} 1$ and $3^{\prime} \mathrm{VP} 2$ primers. Sequencing PCR products of aortic tissue revealed normal sequence in Wistar rats, and homozygotedeleted AVP precursor sequences in Brattleboro rats (Fig. 2A,B). These data demonstrate that in Brattleboro rats the AVP precursor mRNA had the same sequence in both hypothalamus and aorta.

\section{Discussion}

We present evidence in this paper for the presence of AVP precursor gene transcripts in rat aortic tissue and show by direct sequencing that transcripts from aortic tissue of Brattleboro rats display the homozygous deletion $(\Delta \mathrm{G} 316)$.

The detection of AVP precursor gene transcripts in rat aorta is in agreement with previous studies suggesting a local synthesis of AVP in rat aortic tissue by immunocytochemical and radioimmunological investigations (4-7) and extend previous reports on the presence of aortic AVP mRNA $(8,9)$. It should be emphasized that the experiments were designed with primers derived from exon 1 and 3 of the hypothalamic cDNA sequence of the AVP precursor in order to ensure that transcripts contain the full exonic composition. This design was particularly important since it has been reported previously that aberrant AVP transcripts (e.g. truncated precursor composed uniquely of exons 2 and 3) may occur in some tissues such as the testis (13). 
A

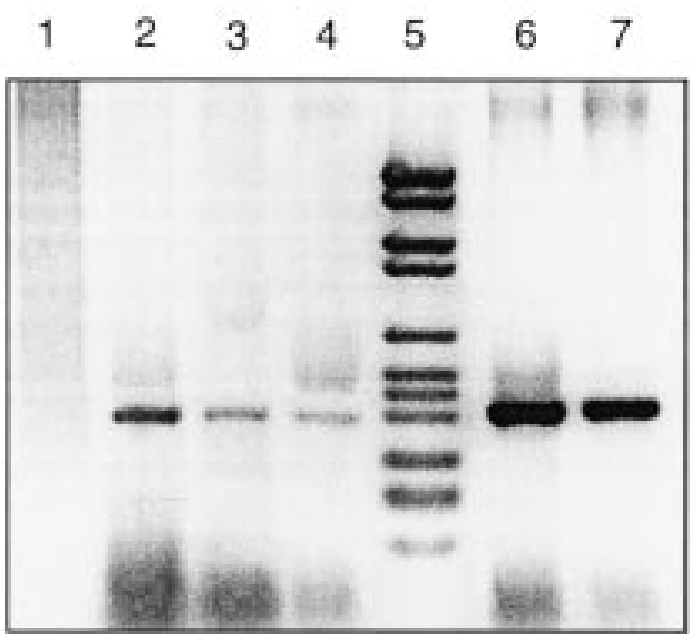

B

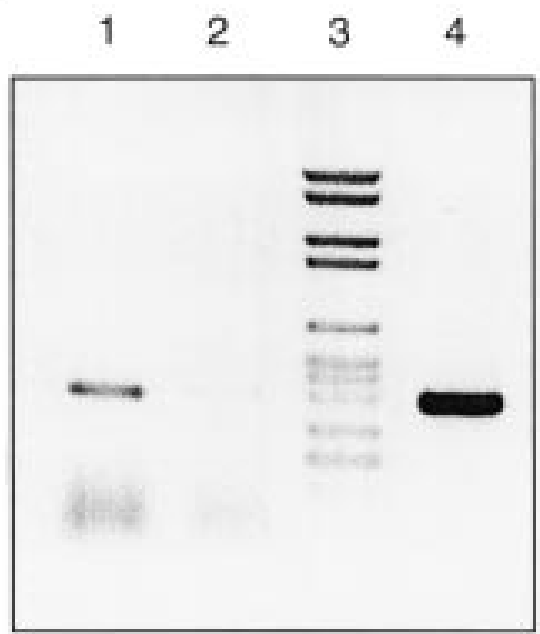

Figure 1 Vasopressin RT-PCR amplified products from rat tissue total RNA. RT-PCR products were resolved in $1.2 \%$ agarose gels, stained with ethidium bromide and visualized under UV light (pictures represent the inversed image). (A) RT-PCR products from aorta and mesenteric artery of normal rat (lanes 2 and 3), aortic tissue from Brattleboro rats (lane 4), hypothalamus from normal and Brattleboro rats (lanes 6 and 7). Lane 1 represents the control without RNA template and lane 5 the molecular size markers (Bgl I-PBR 328 DNA+Hinf I-PBR 328 DNA digest). (B) RT-PCR products from rat aorta before (lane 1) and after (lane 2) endothelium removal compared with normal rat hypothalamic products (lane 4). Lane 3 represents molecular size markers.

Removal of the aortic endothelium dramatically diminished the positive signal of PCR products in at least five repeated experiments, suggesting the location of AVP transcripts mainly in the endothelium. These data are in agreement with numerous immunocytochemical investigations in blood vessels from different species, indicating the endothelial location of AVP (4-6). However, the slight positive signal remaining after the aortic denudation does not exclude the possibility of

\section{A}
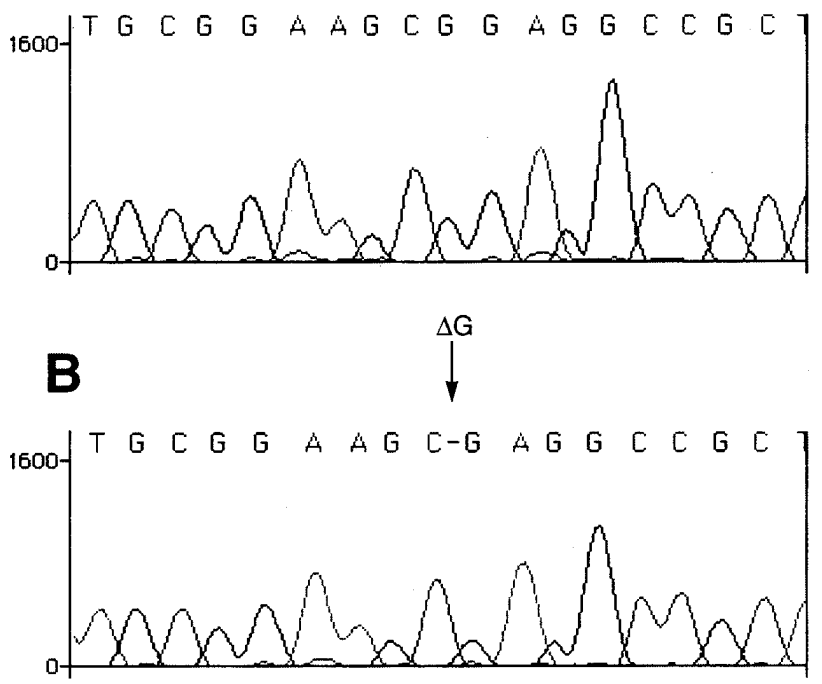

Figure 2 Partial nucleotide sequence of Wistar and Brattleboro aortic AVP precursor gene transcripts. (A) Sequence of normal rat precursor gene transcripts. (B) Sequence of Brattleboro rat precursor gene transcripts. PCR products sequencing was performed with ABI PRISM Dye Terminator Cycle Sequencing Ready Reaction as described in Materials and methods section.

concomitant AVP expression in a non-endothelial compartment, such as smooth muscle cells (8).

Although the definitive origin(s) of AVP precursor gene expression at the aortic level could not be ascertained in our study, sequence data demonstrated the presence of messengers in normal rat aortic tissue and clearly demonstrated that Brattleboro rat aorta contains transcripts with the homozygous deletion $\Delta \mathrm{G} 316$, identical to the mutation seen in hypothalamic transcripts (10).

Since the mutated AVP precursor gene produces an unprocessed AVP precursor in the hypothalamus, it was critical to explore whether the same mutated mRNA was present in peripheral tissues. Our finding is particularly important in the context of doubts about the origin of peripheral AVP. It has previously been postulated that AVP mRNA could result from alternatively spliced processes or even from different AVP genes $(3,14)$. For instance, it was shown by chromatographical criteria that pig testis contains both AVP and lysine vasopressin (LVP) while only LVP is secreted at the level of the hypothalamic-pituitary axis (15). Although our findings could not exclude the co-expression of a distinct precursor gene in peripheral tissues, they favor the hypothesis of the existence of tissue-specific expression of the AVP precursor. Along this line, evidence has been provided for differential polyadenylation resulting in shorter AVP mRNA transcripts which could possibly enter the secretory pathway in peripheral tissues but not in the hypothalamus (3). However, this hypothesis needs further experimental support (11). 
In conclusion, our data from normal rats provide support for vascular synthesis of AVP, mainly at the endothelial level. In the context of doubts about the gene(s) to be expressed in Brattleboro rats, our data favor the hypothesis that tissue-specific mechanisms would be responsible for expression of the AVP precursor gene in hypothalamic nervous tissue versus peripheral tissues. Genetic conditions such as Brattleboro rats or transgenic animals containing mutated AVP precursor gene may contribute further to the understanding of the physiological role of vascular synthesis and AVP secretion.

\section{References}

1 Brownstein MJ, Russell JT \& Gainer H. Synthesis, transport and release of posterior pituitary hormones. Science $1980207373-$ 378.

2 Clements JA \& Funder JW. Arginine vasopressin and oxytocin in organs outside the nervous system. In Frontiers in Neuroendocrinology vol. 10, pp 117-152. Eds L Martini \& WF Ganong. New York: Raven Press, 1988.

3 Ivell R, Schmale H, Krisch B, Nahke P \& Rischter D. Expression of a mutant vasopressin gene: differential polyadenylation and readthrough of the mRNA $3^{\prime}$ end in a frameshift mutant. EMBO Journal 19865 971-977.

4 Loesch A, Tomlinson A \& Burnstock G. Localisation of argininevasopressin in endothelial cells of rat pulmonary artery. Anatomy and Embryology 1991183 129-134.

5 Loesch A, Bodin P \& Burnstock G. Colocalization of endothelin, vasopressin, and serotonin in cultured endothelial cells of rabbit aorta. Peptides 199112 1095-1103.
6 Lincoln J, Loesch A \& Burnstock G. Localisation of vasopressin, serotonin and angiotensin II in endothelial cells of the renal and mesenteric arteries of the rat. Cell and Tissue Research 1990259 341-344.

7 Simon JS, Brody MJ \& Kasson BG. Characterization of vasopressinlike peptide in rat and bovine blood vessels. American Journal of Physiology 1992262 H799-H805.

8 Simon JS \& Kasson BG. Identification of vasopressin mRNA in rat aorta. Hypertension 199525 1030-1033.

9 Nagano K, Toba K, Akishita M, Kozaki K, Eto M. Hashimoto M, Sudoh N, Yoshizumi M \& Ouchi Y. Identification of arginine vasopressin mRNA in rat aortic smooth muscle cells. Biochemical and Biophysical Research Communications 1997231 831-834.

10 Schmale H \& Richter D. Single base deletion in the vasopressin gene is the cause of diabetes insipidus in Brattleboro rats. Nature 1984308 705-709.

11 Schmale H, Borowiak B, Holtgreve-Grez H \& Richter D. Impact of altered protein structures on the intracellular traffic of a mutated vasopressin precursor from Brattleboro rats. European Journal of Biochemistry 1989182 621-627.

12 Rehbein M, Hillers M, Mohr E, Ivell R, Morley S, Schmale H \& Richter D. The neurohypophyseal hormones vasopressin and oxytocin. Biological Chemistry Hoppe Seyler 1986367 695-704.

13 Foo N-C, Carter D, Murphy D \& Ivell R. Vasopressin and oxytocin gene expression in rat testis. Endocrinology 1991128 2118-2128.

14 Fuller PJ, Clements JA, Tregear GW, Nikolaidis I, Whitfeld PL \& Funder JW. Vasopressin-neurophysin II gene expression in the ovary: studies in Sprague-Dawley, Long-Evans and Brattleboro rats. Journal of Endocrinology 1985105 317-321.

15 Nicholson HD, Smith AJ, Birkett SD, Denning-Kendall PA \& Pickering B T. Two vasopressin-like peptides in the pig testis? Journal of Endocrinology 1988117 441-446.

Received 14 January 1998

Accepted 30 March 1998 